INKLUSIF Vol 3. No. 2 Desember 2018

\title{
HALAL KULINER PERSPEKTIF HUKUM ADAT (Analisis Label Halal Pada Makanan Tradisional Nasi Jamblang )
}

\author{
Sidik Lukman Sah ${ }^{1}$ \\ Email : Sidik.al_lukmansah@yahoo.com
}

\begin{abstract}
Halal and haram are important issues for Muslims, especially when talking about food, which concerns the public's needs. In an effort to protect the public against food products, it takes the effort to jointly especially the produced to certify halal labels through LPPOM MUI. The receptie theory states the law that applies to Muslims is their respective customary law. Islamic law can apply if it has been perceived by customary law, so it is a customary law that determines whether there is Islamic law. As a counter theory of this theory, one of them is the Receptie Exit Theory by Hazairin. This theory states that Receptie Theory must exit (exit) from the theory of Indonesian Islamic law, because it is contrary to the 1945 Constitution and the Al-Quran and Hadith, the Hazairin Halal Concept through receptive exit theory is to determine halal it must refer to Islamic Shari'a, traditional food produced and has been passed down from generation to generation in the area or community of Islamic society, it must follow Islamic law. The existence of halal certification and labeling aims to provide inner peace to Muslims as well as the calm of production for producers and increased business profits.
\end{abstract}

Keywords: halal culinary, customary law, Islamic law, Receptie Theory, Receptie Exit Theory, halal certification

\section{ABSTRAK}

Halal dan haram merupakan persoalan penting bagi umat Islam terutama apabila membicarakan berkaitan makanan, yang menyangkut hajat masyarakat luas. Dalam usaha melindungi masyarakat terhadap produk makanan, diperlukan usaha untuk bersama khususnya perodusen untuk melakukan sertifikasi label halal melalui LPPOM MUI.Teori Receptie menyatakan, hukum yang berlaku bagi umat Islam adalah hukum adat mereka masing-masing. Hukum Islam dapat berlaku apabila telah diresepsi oleh hukum adat, jadi hukum adatlah yang menentukan ada tidaknya hukum Islam. Sebagai counter theory terhadap teori ini, salah satunya Teori Receptie Exit oleh Hazairin. Teori ini menyatakan bahwa Teori Receptie harus exit (keluar) dari teori hukum Islam Indonesia, karena bertentangan dengan UUD 1945 serta Al-Quran dan Hadist, Konsep Halal Hazairin melalui teori receptie exit adalah untuk menentukan halal maka harus merujuk pada syariat islam, makanan tradisional yang diproduksi dan sudah diwariskan secara turun temurun yang berada dalam wilayah atau komunitas masyarakat Islam maka harus mengikuti syariat Islam. Adanya sertifkasi serta labelisasi halal bertujuan memberi ketentraman batin pada umat Islam serta ketenangan berproduksi bagi produsen dan peningkatan keuntungan usaha.

Kata Kunci: Halal Kuliner, Hukum Adat, Hukum Islam, Teori Receptie, Teori Receptie Exit, Sertifikasi Halal

\footnotetext{
${ }^{1}$ Mahasiswa Pascasarjana IAIN Syekh Nurjati Cirebon.
} 
INKLUSIF Vol 3. No. 2 Desember 2018

\section{PENDAHULUAN}

\section{A. Latar Belakang}

Halal dan haram secara khusus adalah telah diketahui umum. Pemilihan kepada yang halal adalah wajib bagi setiap umat Islam ${ }^{2}$ dan pada masa yang sama juga meninggalkan yang haram adalah merupakan suatu kewajiban. Dalam usaha mencari yang halal, satu aspek yang kurang diberi perhatian adalah mencari "halal yang baik" (hâlalan thayyiban). Menurut AshShabuni sebagaimana dikutip Kartubi, ${ }^{3}$ menerangkan tentang perintah mengkonsumsi makanan yang halal dan baik, bersamaan dengan itu juga disertai perintah berbuat ketaatan, mengharapkan ridha-Nya dan meninggalkan berbagai kemaksiatan.

Islam tidak membiarkan seseorang (konsumen) muslim untuk mengkonsumsi pangan apa saja lantaran alasan survivalitas hidupnya, melainkan harus mengacu pada tujuan syariah. Dalam konteks ini Islam memperkenalkan konsep halal, haram dan mubazzir sebagai prinsip dasar dalam mengatur kebutuhan-kebutuhannya baik yang bersifat dharuriyat (primer), hajiyat (sekunder) maupun tahsiniyat (tersier). ${ }^{4}$

Persoalan produk halal pernah menjadi polemik di Indonesia antara lain: (1) Tahun 1982 kasus keabsahan mengkonsumsi daging kodok, (2) kasus produk tidak halal pada tahun 1988 yang sempat menimbulkan gejolak. Isu lemak babi yang terjadi pada saat itu merupakan hasil penelitian Dr.Trisusanto dengan mahasiswa yang hasilnya beberapa produk olahan mengandung lemak babi dan (3) Tahun 1993 diadakannya musyawarah MUI tentang alkohol. ${ }^{5}$

Perlindungan konsumen menjadi prioritas utama dalam mengkonsumsi produk halal oleh karena itu pangan menjadi kebutuhan dasar manusia yang paling utama dan pemenuhannya merupakan bagian dari hak asasi setiap rakyat di Indonesia. Pangan harus senantiasa tersedia secara cukup, aman, bermutu, bergizi, dan beragam dengan harga yang terjangkau oleh daya beli masyarakat, serta tidak bertentangan dengan agama, keyakinan, dan budaya masyarakat. Untuk mencapai semua itu, perlu diselenggarakan suatu sistem pangan yang memberikan pelindungan, baik bagi pihak yang memproduksi maupun yang mengonsumsi. Pemanfaatan pangan atau konsumsi pangan akan menghasilkan sumber daya manusia yang berkualitas.

Selama ini sertifikasi halal ditentukan oleh MUI dengan memberikan fatwa terhadap produsen yang menginginkan produknya diaudit, melalui uji coba laboratorium LPPOM MUI (Lembaga Pengkajian Pangan, Obat-obatan dan Kosmetika). Dalam skala nasional, Majelis Ulama Indonesia sebagai lembaga yang memiliki otoritas dalam menetapkan status hukum halal dan haram memprakarsai terbentuknya lembaga pengkajian pangan, obat dan makanan (LPPOM). Lembaga ini diharapkan menjadi master mind bagi terpenuhinya standar kehalalan

2 al-Shaykh Muhammad Jamal al-Din Al-Qasimi, ), Maw“izat Al-Mu"minin Min Ihya' 'Ulum Al-Din, (Beirut: Dar al-Nafa'is, 1994). 187-188.

${ }^{3}$ Kartubi, “Keutamaan Mengkonsumsi Makanan Halalan Thayyiban,” Jurnal Edu-Bio vol 4 (2013): 42.

${ }^{4}$ Muhammad Yusuf Qardhawi, Peran Nilai Dan Moral Dalam Perekonomian Islam. (Jakarta: Rabbani Press, 1995). 13.

${ }^{5}$ Soedarso Soekarno, "Fatwas of The Council of Indonesian Ulama: Astudy of Islamic Legal Thought in Indonesia 1975-1988," INIS (Jakarta: INIS, 1993).21. 
suatu produk pangan yang dihasilkan oleh perusahaan atau industri sebelum diluncurkan secara luas di pasar.

Konsep hukum adat diambil dari teori receptive exit yang dipelopori oleh Hazairin sebagai penolakan terhadap teori receptie yang di pelopori oleh Snouck Hurgronje, adanya teorinya Snouck. Hazairin merasa bahwa teori ini hanyalah mainan Belanda untuk menjaga kekuasaannya aman di Indonesia. Teori receptie exit, teori ini merupakan instrument untuk mengembalikan kedudukan hukum Islam sebagai mitra hukum adat. Sebelumnya, menurut teori receptie, hukum Islam berada di bawah hukum adat. Di bawah teori receptie ini, hukum Islam mendapat segudang stigma negatif termasuk penyudutan kedudukan Islam sebagai pemecah belah keutuhan nasional. Dengan teori receptie exit ini, paling tidak, hukum Islam adalah mitra hukum adat untuk bersama-sama membangun hukum nasional dalam wajah pluralitasnya. Spirit Hazairin ini sebenarnya berhasil menggagas konstitusi yang menghargai keberagaman.

Konsep halal yang dihubungkan dengan hukum adat harus selaras dengan hukum Islam dibutuhkan penelitian lebih dalam untuk menemukan titik terang dari sebuah fenomena halal pada makanan tradisional dengan teori receptie exit konsumen adalah raja' menjadi arah bahwa aktifitas ekonomi khususnya produksi untuk memenuhi kebutuhan konsumen ${ }^{6}$ sesuai dengan kadar relatifitas dari keinginan konsumen. Konsumen dalam hal ini diberikan kebebasan untuk memilih dan menentukan makanan apa yang akan di konsumsi pada pembahasan ini pula diperlukan penelitian lapangan langsung mengenai mengkonsumsi makanan tradisional nasi jamblang dilihat dari ada atau tidak adanya label halal didalamnya.

Penelitian ini lebih menitik beratkan pada konsep halal, serta hukum adat dalam perspektif teori receptive exit yang di cetuskan oleh Hazairin, serta sebagai konsep untuk membahas halal pada makanan tradisional. Lebih dalam pada penelitian ini membahas tentang teori receptive exit yang dihubungkan dengan konsep halal kuliner, yang sebelumnya belum ada yang meneliti dalam kajian ilmiah. Permasalahan dalam penelitian ini adalah: (1) Bagaimana konsep halal dalam prespektif hukum adat menurut Hazairin? (2) Bagaimana penerapan standarlisasi label halal pada produk makanan tradisional dan apakah diperlukan label halal pada produk makanan tradisional nasi jamblang?.

\section{B. Metode Penelitian}

Penelitian ini menggunakan pendekatan kualitatif, dengan jenis field research (penelitian lapangan) dengan mengambil latar di Kota/ Kabupatan Cirebon, pedagang nasi jamblang dan lembaga terkait seperti MUI kabupaten Cirebon, serta tokoh masyarakat. Pengumpulan data dilakukan dengan observasi dan wawancara mendalam. Dalam sebuah wawancara mendalam yang dilakukan pada bulan Juli-Agustus 2018 dengan beberapa informan diantaranya: KH.Dr. Mukhlisin Muzarie M.Ag (Tokoh Masyarakat), KH. Budiman Mahfudz. MBA (Pengurus MUI bidang pemberdayaan ekonomi), Ibu Enok Siti Romlah (Auditor Halal MUI), Susi Susilawati (Owner Nasi Jamblang Ibu Nur), Edi (Owner Nasi jamblang Rose), Adiya Putra (Konsumen), Halimah (Konsumen), Ratna (Konsumen), Nur Amalia (Konsumen).

\footnotetext{
${ }^{6}$ Amdiar Amir Dick, Lanscape Baru Perekonomian Masa Depan (Jakarta: SEBI, 2001).2.
} 
Analisis data dilakukan dengan metode analisis data kualitatif interpretative, analisis data kualitatif dilakukan secara terus menerus pada setiap tahapan penelitian sehingga sampai tuntas dari pendapat-pendapat, pandangan berhubungan dengan adanya tafsiran.

\section{PEMBAHASAN}

\section{A. Konsep Halal dalam Perspektif Hukum Adat Menurut Hazairin}

Berangkat dari fenomena tentang keberadaan makanan tradisional nasi jamblang yang semakin populer serta adanya kajian label halal yang semakin berkembang dengan tujuan untuk mensertifikasi makanan halal dan memberikan rasa aman terhadap konsumen, dalam teori yang di katakan oleh Hazairin dapat diartikan hukum Islam berlaku pada masyarakat islam, dengan begitu makanan tradisonal yang berada dalam wilayah Islam maka wajib menggunakan hukum Islam, pada dasarnya makanan-makanan tradisional dalam tradisi seperti nasi kuning, tumpeng, serta lainnya secara otomatis hukum adat adalah hukum Islam yang mengatur koridor halal atau haram.

Dengan demikian dalam teori receptie exit yang dikemukakan oleh hazairin yang menyatakan bahwa hukum yang berlaku bagi umat Islam di Indonesia adalah hukum Islam. Hukum Adat bisa berlaku jika tidak bertentangan dengan hukum Islam, dari pengertian tersebut secara terbatas bahwa kehalalan kuliner ketika berada di wilayah hukum Islam maka harus menggunakan hukum Islam. Oleh karena itu halal kuliner harus menjamin terlaksananya aturan dan etika budaya dan agama yang ada pada masyarakat, sepanjang adat tidak bertentangan dengan syariat Islam maka hal tersebut diperbolehkan, sikap hukum Islam untuk meresepsi atau menolak adat tergantung pada unsur mashlahah dan unsur mafsadah. Artinya, selama adat tersebut bermanfaat dan tidak mendatangkan kerusakan, adat tersebut dapat terus diberlakukan. Adat seperti itulah yang dapat dijadikan dasar hukum sesuai kaidah AlAdah Mukhamah yang berarti adat itu menjadi dasar penetapan hukum.

Secara etimologi kata Adat berasal dari bahasa Arab yaitu kata al-'adat yang berarti suatu perilaku yang dilakukan secara berulang-ulang sehingga menjadi kebiasaan. Dalam bahasa Indonesia makna Adat adalah Aturan (perbuatan dan sebagaianya) yang lazim diturut atau dilakukan sejak dahulu kala. ${ }^{7}$ Dari term Adat ini munculah istilah Hukum Adat yaitu hukum yang bersumber dari adat dan budaya suatu masyarakat. Dalam wawancara mendalam dari pendapat Mba Halimah ${ }^{8}$ tentang hukum adat " adalah suatu kebiasaan disuatu masyarakat yang sudah turun temurun".

Umat Islam Indonesia patut berterimakasih atas segala upaya dan terobosan-terobosan yang dipersembahkan Hazairin sepanjang hidupnya kepada nusa, bangsa dan agama. Dia merupakan salah satu tokoh yang begitu gigih berada di garda terdepan menyuarakan dan membela keberadaan hukum Islam agar hukum Islam bisa dilaksanakan di bumi nusantara. Dia tampil bersuara keras, ketika Snouck Hurgronje lewat teorinya receptie, melancarkan usahausaha untuk menggusur eksistensi hukum Islam dari Indonesia, dan secara perlahan-lahan

\footnotetext{
7 “Kamus Besar Bahasa Indonesia” (Jakarta: Departemen Pendidikan Nasional, 2008).

${ }^{8}$ Halimah, "Wawancara" (Cirebon: BMT Islamic Centre Kab.Cirebon, n.d.).
} 
menggerogoti wewenang Peradilan Agama. Dia menghujat teori tersebut dengan menyebutnya sebagai teori iblis karena teori yang menghalang-halangi berlakunya hukum Islam di Indonesia, mengajak orang Islam untuk tidak mematuhi dan melaksanakan perintah Allah dan sunnah Rasul-Nya.

Belajar dari teori receptive exit yang di cetuskan oleh Hazairin secara umum teori tersebut berlaku luas pada kajian keilmuan maupun praktek di lapangan. Hazairin menggunakan teori tersebut untuk menyorot system peradilan, perkawinan dan kewarisan, seiring dengan perkembangan jaman dan kemajuan teknologi. Disini penulis menghubungkan teori receptive exit dengan halal kuliner sebagai kebebasan berfikir yang mengedepankan keilmiahan yang relevan, teori tersebut diambil sebagai kacamata dalam memandang "halal" khusunya makanan tradisional dimana peraturan atau pedoman syariah di dalam Al-Quran menjadi pegangan utama untuk memproduksi makanan tradisional mulai dari proses sampai hasil akhir.

Konsep halal yang dapat diambil dari teori tersebut adalah halal harus berdasarkan syariat Islam dengan mengedepankan prinsip tauhid. Ketika dalam memproduksi makanan halal berada di dalam wilayah Islam maka wajib mengganakan syariat Islam di dalamnya tanpa terkecuali baik makanan tradisional maupun modern, adapun tentang sertifikasi label halal pada makanan tradisional nasi jamblang, penulis merekomendasikan untuk produsen untuk mencantumkan label halal dengan alasan sebagai perwujudan perlindungan konsumen.

Merujuk pada teori Receptie Exit yang menyatakan menurut Hazairin, Hukum Islam adalah hukum yang mandiri dan lepas dari pengaruh hukum lainnya. Berdasarkan pandangannya, Hazairin memiliki kesamaan pandangan dengan Van den Berg yang menginginkan hukum Islam diberlakukan sepenuhnya bagi masyarakat Islam (pribumi). Bagi Hazairin, hukum Islam harus diberlakukan bagi orang Islam, baik sudah menjadi hukum adat atau belum. Dari pemikiran hazairin tersebut dapat dikembangkan melalui kajian ilmiah untuk membahas tentang halal kuliner prespektif hukum adat terdapat korelasi antara teori receptive exit dengan konsep halal kuliner, hazairin mengatakan dalam suatu masyarakat Islam harus berlaku hukum Islam dalam ketetapannya, begitu pula untuk menetapkan halal, dalam memproduksi makanan maka wajib menggunakan syariat islam. Kaitanya dengan makanan tradisional sebagai contoh makanan marus (terbuat dari darah yang di endapkan) masyarakat adat sadar dan mengakui kalo marus berbahan darah, secara hukum Islam haram, maka legistimasi hukum yang berlaku adalah hukum Islam bukan lagi hukum adat dari kebiasaan masyarakat mengkonsumsi makanan tersebut.

Dengan demikian eksistensi hukum adat diakui oleh Islam sebagai dalil hukum yang dipertimbangkan dalam menetapkan suatu hukum, selama tidak bertentangan dengan nilainilai Islam. Inilah konsep halal dalam prespektif hazairin yang bisa dipahami dalam memandang hukum dimasyarakat.

\section{B. Penerapan Standarisasi Halal dan Label Halal pada Makanan Tradisional Nasi Jamblang}

Tren gaya hidup manusia modern saat ini sudah mulai meningkat terutama pada upaya memperoleh makanan sehat dan berkualitas. Hal ini berhubungan dengan upaya pemeliharaan 
dan peningkatan derajat kesehatan, kebugaran, dan kualitas hidup manusia mengingat telah banyak korban akibat gaya hidup yang salah di sebagian masyarakat dalam mengonsumsi makanan. contohnya adalah: darah tinggi, jantung, stroke, asam urat, kolesterol, dan sebagainya telah menjadi trauma bagi sebagian masyarakat.

Hikmah dari fenomena tersebut telah menumbuhkan kesadaran pada diri masyarakat untuk kembali menikmati makanan yang memiliki standar kualitas sehat dan baik. Jawaban atas kegundahan tersebut sebenarnya telah dimiliki oleh ajaran agama Islam. Bersumber pada Al-Quran, ada 31 ayat yang merujuk pada konsep halal. Adapun ayat yang secara eksplisit merujuk kepada makanan dan minuman ada 16 ayat. Di antaranya adalah: ${ }^{9}$

1. Hai sekalian manusia, makanlah yang halal lagi baik dari apa yang terdapat di bumi, dan janganlah kamu mengikuti langkah-langkah syaitan; karena sesungguhnya syaitan itu adalah musuh yang nyata bagimu. (Q.S Al Baqarah: 168)

2. Semua makanan adalah halal bagi Bani Israil melainkan makanan yang diharamkan oleh Israil (Ya'qub) untuk dirinya sendiri sebelum Taurat diturunkan. Katakanlah: "(Jika kamu mengatakan ada makanan yang diharamkan sebelum turun Taurat), maka bawalah Taurat itu, lalu bacalah dia jika kamu orang-orang yang benar". Q.S Ali Imran: 93 (makanan halal bani Israil)

3. Pada hari ini dihalalkan bagimu yang baik-baik. Makanan (sembelihan) orang-orang yang diberi Al Kitab itu halal bagimu, dan makanan kamu halal (pula) bagi mereka. (Dan dihalalkan mangawini) wanita yang menjaga kehormatan diantara wanita-wanita yang beriman dan wanita-wanita yang menjaga kehormatan di antara orang-orang yang diberi Al Kitab sebelum kamu, bila kamu telah membayar mas kawin mereka dengan maksud menikahinya, tidak dengan maksud berzina dan tidak (pula) menjadikannya gundik-gundik. Barangsiapa yang kafir sesudah beriman (tidak menerima hukum-hukum Islam) maka hapuslah amalannya dan ia di hari kiamat termasuk orang-orang merugi. Q.S Al Maidah: 5 (makanan sembelihan).

4. Dan makanlah makanan yang halal lagi baik dari apa yang Allah telah rezekikan kepadamu, dan bertakwalah kepada Allah yang kamu beriman kepada-Nya. Q.S Al Maidah: 88 (makanan halal dan baik).

5. Maka makanlah dari sebagian rampasan perang yang telah kamu ambil itu, sebagai makanan yang halal lagi baik, dan bertakwalah kepada Allah; sesungguhnya Allah Maha Pengampun lagi Maha Penyayang. Q.S Al Anfaal: 69 (perolehan makanan).

Secara makna halal bermakna dibenarkan. Istilah haram artinya dilarang, atau tidak dibenarkan menurut syariat Islam. Islam sangat memperhatikan aspek syariat dan kulitas/mutu makanan yang tujuannya adalah menyelamatkan dan menyehatkan diri manusia.

\footnotetext{
${ }^{9}$ Riadi Darwis, “. Inventarisasi Khazanah Kuliner Tradisional Desa Pakuwon Kecamatan Cisurupan Kabupaten Garut Dalam Konteks Pembangunan Kampungwisata Halal.," Sekolah Tinggi Pariwisata Bandung Jurnal Vol (n.d.): 243-45.
} 
Rofi'i ${ }^{10}$ menjelaskan lebih lanjut bahwa "Dalam ajaran Islam, semua jenis makanan dan minuman pada dasarnya adalah halal, kecuali hanya beberapa saja yang diharamkan. Yang haram itu pun menjadi halal bila dalam keadaan darurat. Sebaliknya, yang halal pun bisa menjadi haram bila dikonsumsi melampaui batas. Ditegaskannya pula bahwa pemahaman halal dan haram ini termasuk pula pada aspek perbuatan.

Informasi status halal atau haramnya suatu produk diketahui dari label halal yang diperoleh berdasarkan Sertifikat Halal, yaitu fatwa tertulis yang dikeluarkan oleh Majelis Ulama Indonesia (MUI) berdasarkan proses audit (penelitian dari aspek sains) yang dilakukan oleh Lembaga Pengkajian Pangan, Obat-Obatan, dan Kosmetika Majelis Ulama Indonesia (LPPOM MUI). ${ }^{11}$

Fatwa MUI terhadap makanan halal dan haram menjadi hak MUI dalam ketetapannya, pada dasarnya masih banyak lembaga terkait serta elemen masyarakat adat untuk menetapkan label halal pada makanan yang beredar luas di masyarakat. Penetapan Fatwa Halal itu sendiri didasarkan pada tiga prinsip, yaitu ketentuan syariah, kaidah ilmiah, dan kultur masyarakat. Ketentuan syariah merupakan prinsip dasar yang bersumber dari Al-Qur'an dan Hadits. Kaidah ilmiah yaitu aplikasi dari perkembangan iptek dalam proses pengolahan bahan pangan. Sementara kultur masyarakat adalah kebiasaan masyarakat setempat, misalnya Rumah Potong Hewan (RPH) yang halal harus terpisah dari rumah potong babi. ${ }^{12}$

Salah satu contoh dalam fatwa MUI terkait makanan halal adalah: alcohol. Dari hasil kesepakatan MUI, makanan dan minuman yang mengandung alkohol tidak boleh melebihi $1 \%$, sehingga makanan dan minuman yang mengandung kadar alkohol melebihi $1 \%$ termasuk dalam katagori haram untuk dikonsumsi. ${ }^{13}$

Penerapan standarlisasi halal pada makanan harus sesuai dengan Sistem Jaminan Halal (SJH) yaitu sebuah sistem yang mengelaborasi, menghubungkan, mengakomodasi dan mengintegrasikan konsep-konsep syariat Islam khususnya terkait dengan halal dan haram, etika usaha dan manajemen keseluruhan, prosedur dan mekanisme perencanaan serta implementasi dan evaluasinya pada suatu rangkaian produksi atau olahan bahan yang akan dikonsumsi umat Islam.

Produk halal adalah produk yang memenuhi syarat kehalalan sesuai dengan syariat Islam, ${ }^{14}$ yaitu: (1) Tidak mengandung babi dan bahan yang berasal dari babi. (2) Tidak mengandung bahan-bahan yang diharamkan seperti bahan-bahan yang berasal dari organ manusia, darah, kotoran dan lain-lain. (3) Semua bahan yang berasal dari hewan halal yang disembelih menurut tata cara syariat Islam. (4) Semua tempat penyimpanan, penjualan, pengolahan, tempat pengelolaan dan transportasinya tidak boleh digunakan untuk babi. Jika pernah digunakan untuk babi atau barang yang tidak halal lainnya maka terlebih dahulu harus

\footnotetext{
${ }^{10}$ Rofi'i, Sunhadji, “Pengertian Halal Dan Haram Menurut Ajaran Islam,” online, 2010, http://www.halalmuibali.or.id/?p=56.

${ }^{11}$ Majelis Ulama indonesia, "Panduan Umum Sistem Jaminan Halal LPPOM MUI" (Jakarta, 2008), http://www.halalmui.org/images/ stories/pdf/sjh-indonesia.pdf,.1.

12 “Keputusan Dewan Pimpinan Majelis Ulama Indonesia Nomor: Kep.311/MUI/IX/2000,” n.d.

${ }^{13}$ A Apriyantono, “Tape," 2005, http://groups.yahoo.com/group/Halal Baik-Enak/message/5632.

${ }^{14}$ Departemen Agama Republik Indonesia, Panduan Sertifkasi Halal (Jakarta: Departemen Agama RI, 2003$) .2$.
} 
dibersihkan dengan tata cara yang diatur menurut syariat Islam. (5) Semua makanan dan minuman yang tidak mengandung khamar.

Pemaknaan makanan dan minuman halal dalam ajaran Islam meliputi aspek-aspek berikut: (1) dzatnya, (2) cara memprosesnya, dan (3) cara memperolehnya. Adapun hikmah adanya makanan dan minuman halal dan haram yang diberlakukan pada umat manusia, pada hakikatnya untuk: (1) jadi bahan ujian keimanan dan ketakwaan manusia; (2) upaya perlindungan kesehatan manusia; serta (3) upaya menjauhkan dari perilaku yang buruk mengingat antara dzat, proses, dan perolehannya terdapat hubungan yang signifikan terhadap kualitas spiritual pribadinya.

Dalam perkembangan jaman keberadaan nasi jamblang masih tetap eksis dalam dunia kuliner tidak lepas dari rasanya yang cocok untuk masyarakat indonesia, nasi jamblang mengalami berbagai pengkondisian aturan khususnya lahirnya. Undang-Undang Nomor 33 Tahun 2014 tentang Jaminan Produk Halal (UU-JPH) memperkuat dan mengatur berbagai regulasi halal yang selama ini tersebar di berbagai peraturan perundang-undangan, di sisi lain UUJPH dapat disebut sebagai payung hukum (umbrella act) bagi pengaturan produk halal dan Pasal 1, Angka (3),Peraturan Pemerintah Nomor 69 Tahun1999 tentang Label dan Iklan Pangan, adalah "Setiap keterangan mengenai pangan yang berbentuk gambar, tulisan, kombinasi keduanya, atau bentuk lain yang disertakan pada pangan, dimasukkan ke dalam, ditempelkan pada, atau merupakan bagian kemasan pangan, yang selanjutnya disebut label."

Pencantuman label halal ditujukan untuk melindungi masyarakat yang beragama Islam agar terhindar dari produk makanan yang tidak halal, menjadi polemik tersendiri bagi pedagang atau pengusaha makanan tradisional yang secara turun temurun sudah mendarah daging bagi masyarakat yang mengkonsumsi makanan tradisional tersebut salah satunya nasi jamblang, sistem jaminan halal diperlukan kajian juga dengan hukum adat atau kearifan masyarakat lokal agar tidak terjadi gesekan di dalam masyarakat, dan dalam prakteknya produk halal adalah produk yang telah dinyatakan halal sesuai dengan syariat Islam. 
INKLUSIF Vol 3. No. 2 Desember 2018

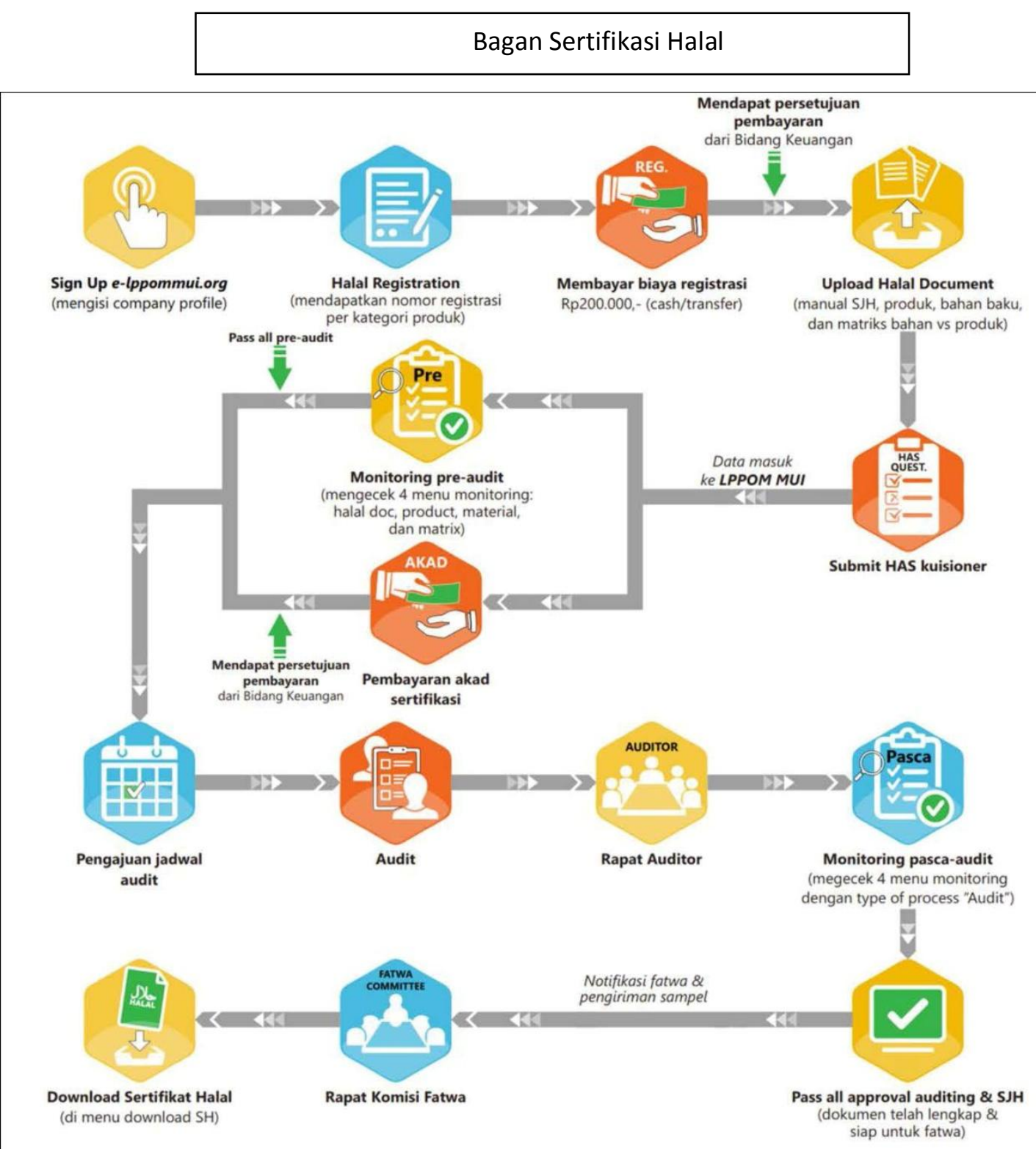

Sertifikat halal merupakan fatwa tertulis yang diterbitkan oleh MUI untuk produk yang telah dinyatakan halal setelah melalui proses pendaftaran, audit dan rapat Komisi Fatwa MUI. Pada tataran praktik di Indonesia usaha untuk memberikan proteksi terhadap hak-hak konsumen Muslim dinyatakan melalui Surat Keputusan (SK) Menteri Agama Nomor 518 tanggal 30 November 2011 tentang Tata Cara Pemeriksaan dan Penetapan Pangan Halal. Tampaknya Pemerintah berusaha kembali menerapkan labelisasi halal pada produk makanan dan minuman. ${ }^{15}$ hal ini bertujuan untuk melindungi konsumen luas.

Berdasarkan wawancara mendalam yang dilakukan peneliti terhadap informan mengenai pengertian atau konsep halal kuliner diperoleh hasil yang hampir serupa antar jawaban yang satu dengan jawaban lainnya dari masing-masing informan.

${ }^{15}$ Mazhida, “'Label Halal Dan Ikhtiar Perlindungan Konsumen,'” 2009, www.mazhida.wordpress.com,. 
Sebagaimana yang disampaikan oleh $\mathrm{KH}$. Dr Mukhlisin ${ }^{16}$ "halal merupakan segala sesuatu yang di bolehkan sesuai dengan syariat islam yang perlu digaris bawahi untk diperhatikan disini adalah zat dan proses, berbicara mengeni zat harus merujuk pada kebersihan, dan pemeriksaan menyeluruh terkait kandungan makanan dan yang kedua proses cara memperoleh harus sesuai dengan syariat islam mengedepankan kejujuran".

Hal serupa disampaikan oleh $\mathrm{KH}$. Budiman ${ }^{17}$ “ halal dibolehkan dan harus dilihat dari zat apakah mengandung zat yang haram seperti babi dan yang kedua dilihat dari proses dari awal pembuatan sampai hasil jadi harus menghindari dari sesuatu yang haram, disamping itu nilainiai etika dan kejujuran bahwa makanan yang diperjualbelikan tersebut halal menjadi sangat penting untuk diperhatikan"

Begitu juga yang disampaikan oleh Mba Ratna ${ }^{18}$ konsumen makanan tradisional nasi jamblang menyatakan bahwa "halal adalah diperbolehkan sesuai syariat agama islam" dengan demikian halal dapat diartikan sebagai sesuatu yang diperbolehkan menurut ketentuan syariat islam, karena kita berada didalam lingkungan muslim dan yang harus diperhatikan adalah proses serta zat dari mulai awal sampai akhir dalam produksi barang/makanan.

Pada kesempatan yang sama peneliti menanyakan hal yang berhubungan dengan halal kuliner yakni label halal. Adanya regulasi tentang sertifikasi halal sebuah produk baik makanan, obat-obatan maupun kosmetik merupakan bagian dari perlindungan terhadap konsumen khususnya yang beragama Islam. Sertifkat halal adalah fatwa tertulis Majelis Ulama Indonesia (MUI) yang menyatakan kehalalan suatu produk sesuai dengan syariat Islam. ${ }^{19}$

Berdasarkan wawancara mendalam yang dilakukan kepada informan dilapangan kaitanya dengan sertifikasi halal pada makanan tradisional, seperti yang disampaikan oleh ibu enok $^{20}$ "sertifikasi halal merupakan keharusan bagi produsen tanpa kecuali baik pedagang kecil, UMKM, maupun perusahaan dalam skala besar, hal ini bertujuan untuk memberikan ketenangan dan kenyamanan konsumen, disamping itu manfaat sertifikasi bagi produsen dapat meningkatkan asset atau keuntungan"

Kemudian lebih lanjut dari hasil wawancara langsung dengan produsen makanan nasi jamblang ibu susi susilawati ${ }^{21}$ mengatakan" sebenarnya sertifikasi halal diperlukan akan tetapi bagi produsen masih menjadi kendala hal ini karena biaya yang dikeluarkan cukup besar terlebih makanan yang banyak jenisnya seperti lauk pauk nasi jamblang sangat banyak ini salah satu kendalanya juga", lebih lanjut ibu susi menjelaskan "kalo makanan tradisional seperti nasi jamblang ini turun temurun secara spesifik dari mulai bahan, cara pembuatan, proses sampai penyajian sangat diperhatikan kebersihan dan kehalalnnya jadi saya yakin kalau ini semua sudah halal".

\footnotetext{
${ }^{16}$ KH.Dr Mukhlisin, "Wawancara” (Cirebon: jln. Serayu-Arjawinangun, n.d.).

${ }^{17} \mathrm{KH}$. Budiman, "Wawancara" (BAZNAS Kab. Cirebon, n.d.).

${ }^{18}$ Ratna, "Wawancara" (Cirebon: BMT Islamic Centre Kab Cirebon, n.d.).

${ }^{19}$ Departemen Agama Republik Indonesia, Panduan Sertifkasi Halal (Jakarta: Departemen Agama RI, 2003).1-2.

${ }^{20}$ Enok Siti Romlah, "Wawancara” (Cirebon: Perumahan Kali Wulu-Plered, n.d.).

${ }^{21}$ Susi Susilawati, "Wawancara” (Cirebon: Warung nasi Jamblang Ibu Nur, n.d.).
} 
Pendapat serupa tentang proses sertifikasi label halal pada makanan tradisional nasi jamblang disampaikan oleh Pak Edi ${ }^{22}$ "adanya label halal sebenarnya mendukung usaha akan tetapi prosedur yang rumit serta lamanya proses membuat males untuk melakukannya, dan pada dasarnya makanan tradisional nasi jamblang sudah ada sejak lama di Cirebon sehingga kepercayaan masyarakat sudah terbentuk lama dan sudah terbiasa bahwa yang mereka konsumsi baik dan enak".

Pendapat berbeda yang dikemukakan di atas seperti yang katakan oleh KH. Dr. Mukhlisin merujuk pada teori receptive exit yang dicetuskan oleh Hazairin, "hukum Islam harus diberlakukan bagi orang Islam, baik sudah menjadi hukum adat atau belum" dalam wawancara mendalam yang dihubungkan dengan konsep halal menyatakan " pada dasarnya makanan halal yang diproses oleh orang Islam di dalam lingkungan Islam harus mengikuti ketentuan syariat Islam yang berlaku tanpa kecuali, adapun sertifikasi halal sebenarnya tidak terlalu dibutuhkan dalam konteks hukum adat karena sudah berlaku ketentuan syariat Islam untuk proses membuat makanan tradisional tersebut".

Pendapat yang serupa disampaikan konsumen makanan tradisional nasi jamblang Bapak Adhitya Putra ${ }^{23}$ yang menyatakan "untuk pencantuman sertifikasi halal pada makanan tradisional nasi jamblang sebenarnya tidak terlalu dibutuhkan alasanya makanan tradisional diwariskan secara turun temurun yang sebelumnya nenek moyang kita sudah menjaminya sehingga tidak diperlukan lagi sertifikasi halal, nasi jamblang sudah memenuhi ketentuan halal bias dilihat dari bahan baku dan cara pembuatannya yang masih menjaga warisan resep nenek moyang".

Dalam teori receptive exit yang dikemukakan oleh Hazairin yang dihubungkan dengan hukum adat dalam memandang bahwa hukum agama (Hukum Islam) menjadi dasar yang paling dominan, dimana hukum Islam sangat berperan dalam membentuk perilaku manusia di Indonesia. Oleh karenanya hukum Islam menjadi unsur mutlak bagi pembangunan hukum nasional Indonesia. Oleh sebab itu dalam kaitanya dengan halal kuliner, makanan tradisional yang diproduksi dan sudah diwariskan secara turun temurun yang berada dalam wilayah atau komunitas masyarakat Islam maka harus mengikuti syariat islam.

Penerapan standarlisasi halal pada makanan harus sesuai dengan Sistem Jaminan Halal (SJH) yaitu sebuah sistem yang mengelaborasi, menghubungkan, mengakomodasi dan mengintegrasikan konsep-konsep syariat Islam khususnya terkait dengan halal dan haram, etika usaha dan manajemen keseluruhan, prosedur dan mekanisme perencanaan serta implementasi dan evaluasinya pada suatu rangkaian produksi atau olahan bahan yang akan dikonsumsi umat Islam. $^{24}$

Dilihat dari berbagai prespektif memang sertifikasi halal memiliki dampak positif baik bagi produsen maupun bagi konsumen, akan tetapi masih ada beberapa kendala di lapangan seperti bagi produsen mengeluhkan biaya yang cukup tinggi dan proses yang masih rumit untuk mendaftarkan produk usahanya, serta bagi konsumen kebanyakan dari mereka belum

\footnotetext{
${ }^{22}$ Edi, "Wawancara" (Cirebon: Warung nasi Jamblang Ibu Rose, n.d.).

${ }^{23}$ Adhitya Putra, "Wawancara" (Cirebon: BMT Islamic Centre Cab Arjawinangun, n.d.).

${ }^{24}$ Dr. Ir Anton Apriyantono.
} 
mengetahui keuntungan dengan pencantuman label halal, konsumen Indonesia masih berpegang pada kepercayaan terlebih makanan tradisional, masih ada konsumen makanan tradisional menyampingkan halal karena dengan alasan makanan tradisional sudah turun temurun warisan nenek moyang yang sudah pasti halal sehingga tidak diperlukan lagi sertifikasi halal.

\section{PENUTUP}

Teori receptie exit yang dikemukakan oleh Hazairin teori ini menyatakan bahwa hukum yang berlaku bagi umat Islam di Indonesia adalah hukum Islam. Kemudian dihubungkan dengan konsep halal yang dapat diambil dari teori tersebut adalah halal harus berdasarkan syariat Islam dengan mengedepankan prinsip tauhid. Ketika dalam memproduksi makanan halal berada di dalam wilayah Islam maka wajib menggunakan syariat Islam di dalamnya tanpa terkecuali baik makanan tradisional maupun modern kaitanya dengan halal kuliner. Makanan tradisional dalam konteks hukum adat harus tidak bertentangan syariat Islam maka hal tersebut bisa dibenarkan dan dipertanggungjawabkan nilai halalnya tersebut.

Sertifikasi halal memiliki dampak positif baik bagi produsen maupun bagi konsumen, akan tetapi masih ada beberapa kendala di lapangan seperti bagi produsen mengeluhkan biaya yang cukup tinggi dan proses yang masih rumit untuk mendaftarkan produk usahanya, serta bagi konsumen kebanyakan dari mereka belum mengetahui keuntungan dengan pencantuman label halal, konsumen Indonesia masih berpegang pada kepercayaan terlebih makanan tradisional, masih ada konsumen makanan tradisional menyampingkan halal karena dengan alasan makanan tradisional sudah turun temurun warisan nenek moyang yang sudah pasti halal sehingga tidak diperlukan lagi sertifikasi halal bagi makanan tradisional nasi jamblang.

\section{DAFTAR PUSTAKA}

Adhitya Putra. "Wawancara." Cirebon: BMT Islamic Centre Cab Arjawinangun, n.d.

Ahmad Fahmi Abu Sinnah. Al-Urf Wa Al-Adah Fi Ra'yi Al-Fuqaha. Mesir: Mathba'ah al-Azhar, 1947. Al-Nawawi. Al-Majmu" Syaraḥal-Muhażżab. Juz IX., n.d.

Al-Qasimi, al-Shaykh Muhammad Jamal al-Din. ), Maw"izat Al-Mu"minin Min Ihya' 'Ulum Al-Din,. Beirut: Dar al-Nafa'is, 1994.

Al-Suyuti. Al-Ashbah Wa Al-Naza'ir. Lubnan: Dar al-Kutub, 2001.

Apriyantono, A. "Tape," 2005. http://groups.yahoo.com/group/Halal Baik-Enak/message/5632.

At-Tirmiżi. Sunan at-Tirmiżi. III no. ha., n.d.

Departemen Agama Republik Indonesia. Panduan Sertifkasi Halal. Jakarta: Departemen Agama RI, 2003.

- - Panduan Sertifkasi Halal. Jakarta: Departemen Agama RI, 2003.

Dick, Amdiar Amir. Lanscape Baru Perekonomian Masa Depan. Jakarta: SEBI, 2001.

Dr. Ir Anton Apriyantono, M.Sc. "Jurnal Halal." Lifestile Halal vol 2 (2013): 48.

Edi. "Wawancara." Cirebon: Warung nasi Jamblang Ibu Rose, n.d.

Enok Siti Romlah. "Wawancara." Cirebon: Perumahan Kali Wulu-Plered, n.d.

Halimah. "Wawancara." Cirebon: BMT Islamic Centre Kab.Cirebon, n.d.

Imam Gunawan. Metode Penelitian Kualitatif: Teori Dan Praktik. Jakarta: Bumi Aksara, 2013.

Ismoyowati, Dyah. “'Halal Food Marketing: A CaseStudy on Consumer Behaviorof Chickenbased 
Processed Food Consumptionin Central Part of Java."' Agriculture and Agricultural Sciene Procedia 3, 2015, 169-72.

"Kamus Besar Bahasa Indonesia." Jakarta: Departemen Pendidikan Nasional, 2008.

Kartubi. "Keutamaan Mengkonsumsi Makanan Halalan Thayyiban." Jurnal Edu-Bio vol 4 (2013): 42.

"Keputusan Dewan Pimpinan Majelis Ulama Indonesia Nomor: Kep.311/MUI/IX/2000," n.d.

KH. Budiman. "Wawancara." BAZNAS Kab. Cirebon, n.d.

KH.Dr Mukhlisin. "Wawancara." Cirebon: jln. Serayu-Arjawinangun, n.d.

Majelis Ulama indonesia. "Panduan Umum Sistem Jaminan Halal LPPOM MUI." Jakarta, 2008. http://www.halalmui.org/images/ stories/pdf/sjh-indonesia.pdf,.

Mazhida. "'Label Halal Dan Ikhtiar Perlindungan Konsumen,'” 2009. www.mazhida.wordpress.com,.

Meleong, Lexi J. Metodologi Penelitian Kualitatif. Bandung: PT. Remaja Rosda Karya, 2002.

Mohani Abdul. "Indonesian Small Medium Enterprise (SMEs) and Perception on Halal Food Certication."' African Journal of Business Management Vol.7(16), (2013): pp.1492-1500.

Muhammad Aziz. "Mengkonsumsi Makanan Halal Perspektif Alqu'ran Upaya Menemukan Makna Makanan Halal (Kajian Dengan Pendekatan Teori Fungsi Interpretasi Jorge J.E. Gracia)." Jurnal Syariah Dan Hukum Islam (Al-'Adalah) ISSN 2503- (2015): 15-35.

Qardhawi, Muhammad Yusuf. Peran Nilai Dan Moral Dalam Perekonomian Islam. Jakarta: Rabbani Press, 1995.

Rahimah Mohamed Yunos. "."Understanding Mechanisms to Promote Halal Industry-the Stakeholder's Views"." Procedia - Social and Behavioral Sciences 130, 2014, 160-66.

Ratna. "Wawancara." Cirebon: BMT Islamic Centre Kab Cirebon, n.d.

Riadi Darwis. ". Inventarisasi Khazanah Kuliner Tradisional Desa Pakuwon Kecamatan Cisurupan Kabupaten Garut Dalam Konteks Pembangunan Kampungwisata Halal." Sekolah Tinggi Pariwisata Bandung Jurnal Vol (n.d.): 243-45.

Rofi'i, Sunhadji. "Pengertian Halal Dan Haram Menurut Ajaran Islam." online, 2010. http://www.halalmuibali.or.id/?p=56.

Sariwati Mohd Shariff. Nurul Akma AbdLah. "'Halal Certificationon Chocolate. A Case Study."” Procedia - Social and Behavioral Sciences 121, 2014, 104-112.

Soekarno, Soedarso. "Fatwas of The Council of Indonesian Ulama: Astudy of Islamic Legal Thought in Indonesia 1975-1988." INIS. Jakarta: INIS, 1993.

Susi Susilawati. "Wawancara." Cirebon: Warung nasi Jamblang Ibu Nur, n.d.

Tuan Sidek T. M. dan Ridzwan Ahmad. "Aplikasi Al-Istihalah Dalam Industri Halal Semasa Menurut Perspektif Maqasid Al-Shariah (The Application of Al-Istihalah in Current Halal Industry From The Perspective of Maqasid Al-Shari'ah)." International Journal of Humanities Technology and Civilization Vol. 2, No (2017): 1-9.

Zahra, Abu. Ushul Al-Figh. Mesir: Dar al-Fikr al-Arabi, 1958. 